\title{
THE TOURIST TRAILS DEVELOPMENT IN THE PROTECTION PLANS OF THE LOWER SILESIAN LANDSCAPE PARKS
}

\author{
BARBARA MASTALSKA-CETERA, ${ }^{1}$ PIOTR KRAJEWSKI ${ }^{2}$
}

Wroclaw University of Environmental and Life Sciences, POLAND

${ }^{1}$ e-mail: barbara.mastalska-cetera@up.wroc.pl

2 e-mail: piotr.krajewski@up.wroc.pl

\begin{abstract}
KEYWORDS | landscape park, tourist trail, protection plan, Lower Silesia, nature conservation
ABSTRACT Landscape parks are created to protect the unique natural, landscape and cultural resources. Nature conservation objectives of the parks are often in conflict with their tourist and recreational functions. In order to enable tourists to enjoy the values of the parks tourist infrastructure should be adequate. One of the elements of tourist infrastructure are tourist trails. The system of the trails and their technical condition have a great influence on management of tourist traffic. The aim of the study is to analyze protection plans of Lower Silesian landscape parks in terms of the guidelines for the development of tourism infrastructure. Protection plans in part relating to tourism development have been analyzed for 8 of the 12 parks in the Lower Silesia Province. This part of documentation identify potential and actual risks within the landscape parks and determine how to eliminate these risks. It provides a basis for proper planning of tourism development taking into account the nature and landscape protection. The analyzes show that in most of the parks the system of tourist trails is correct but there are some proposals for single additions. the need to maintain good condition of tourist trails, eliminate problem of bad marking of the trails and the need for better management of tourist traffic in single parks are also pointed out.
\end{abstract}

\section{Introduction}

Environmental elements, economic, organizational and legal factors are considered the basic conditions for the development of tourism. They are closely linked to each other. Natural and landscape values of the region strongly influence on the interest of potential tourists, however, to enjoy the values they have to be available. The basic principle should be to maintain a balance between the social demand and the potential of the environment. The poorly developed tourism 
infrastructure, including bad condition of the tourist trails, may cause the threats to natural and landscape resources. This is particularly important for areas with unique values. Their specificity is secured with the possible forms of protection and is available for tourists at the same time. But nature conservation objectives are often in conflict with tourist and recreational functions. However, these conflicts are mostly caused by the weak diversification of tourist offer, seasonality of tourist traffic or the desire of achieving quick profits. ${ }^{1}$ Detailed studies of all the circumstances of the region should be the basis for the proper control of tourism development and planning of tourist infrastructure. This refers to the role of protection plans prepared for Polish national parks, nature reserves, landscape parks and Natura 2,000 areas.

The aim of this study is to analyze protection plans of landscape parks in terms of the need for the development of tourist infrastructure within their borders. Documents for 8 of the 12 parks in the Lower Silesia Province have been analyzed. The studies have been preceded by an analysis of tourist trails in selected landscape parks. The current condition of tourist infrastructure has been compared to the guidelines contained in the protection plans for the selected parks.

\section{Tourist infrastructure}

Tourism can be considered on various planes. Firstly, in terms of people (tourists) movement, secondly as a transformation of the land adapting it to the needs of arriving people. One can tell that the main aim of tourism is adapting the most attractive areas for tourist penetration. In this case, tourism should be treated as a spatial phenomenon. ${ }^{2}$

In the literature on the subject, there is a lot of attempts to define the concept of tourist infrastructure. A. Kowalczyk and M. Derek claim that tourist infrastructure is a system of tourist devices and services existing within the selected area which make geographical space values available for tourists. ${ }^{3}$ Among them are the basic elements of infrastructure such as accommodation or tourist trails, but also the nutritional base or accompanying base e.g. sports and recreation areas. Tourist infrastructure often generates conflict situations which arise as a result of tourism's impact on the environment, impact on other socio-economic features of the region, but also can occur between different forms of tourism. ${ }^{4}$ Clashes between tourism and the natural environment usually arise at the time when natural resources become available. It is usually associated with the devastation of nature as a direct result of the tourists penetration. Other reasons are the exploitation of resources and too intense and chaotic development of tourist infrastructure. That is why the basic principle that should be taken into account when planning the tourism development is to satisfy the needs

${ }^{1}$ R. Ziółkowski, Funkcje turystyczno-rekreacyjne obszarowej ochrony przyrody w świetle uwarunkowań prawnych, in: Turystyka i rekreacja na obszarach przyrodniczo cennych w regionach transgranicznych pótnocno-wschodniej Polski, ed. W. Chiżniak, Oficyna Wydawnicza Politechniki Białostockiej, Białystok 2009, pp. 18-31.

${ }^{2}$ W. Kurek, M. Mika, Turystyka jako przedmiot badań naukowych, in: Turystyka, ed. W. Kurek, Wydawnictwo Naukowe PWN, Warszawa 2008, pp. 11-49.

${ }^{3}$ A. Kowalczyk, M. Derek, Przedmiot zagospodarowania turystycznego, in: Zagospodarowanie turystyczne, eds. A. Kowalczyk, M. Derek, Wydawnictwo Naukowe PWN, Warszawa 2010, pp. 13-117.

${ }^{4}$ W. Kurek, M. Mika, op.cit. 
of tourists, but most of all the attention should be paid to protect of natural and cultural resources. ${ }^{5}$ According to Kowalczyk and Derek such an approach refers to the concept of sustainable tourism. It should also be emphasized that relations between tourists and the natural environment have been study object for many authors before formulating the principles of sustainable development. ${ }^{6}$

Tourist traffic should be managed in such a way as not to cause environmental damage. Particular care must be taken when using resources within the borders of valuable areas. According to A. Demianowicz and B. Pawichrowska, and in the light of the principles of sustainable development, the tourist infrastructure of protected areas should:

- use natural resources in a rational way,

- prevent degradation by controlling the tourist traffic,

- ensure proper contact with nature,

- cause the penetration places to appear more attractive,

- guarantee obtaining financial profits by the local community. ${ }^{7}$

There are three main tourism management techniques for reducing negative impact of tourist traffic proposed by S. Wiliams which can be applied in the protected areas: spatial zoning, spatial concentration or dispersal of tourists, and the restrictive entry or pricing. ${ }^{8}$ For this purpose in Poland and other countries there are zones considered to be excluded from the tourists penetration and zones with a specific intensity of tourist traffic. H. Kiryluk claims that among the many causes of threats to natural values particular importance should be assigned to excessive concentration of tourists in a relatively small area or around the most attractive places and improper deployment or insufficient number of tourist infrastructure. Risks may arise as a result of the low level of environmental awareness or inadequately tourism policy of communes located within valuable areas. ${ }^{9}$ The cause of conflicts and threats are poorly defined guidelines of tourism development they are often inadequate and have no relation to reality.

\section{Tourist trails}

One of the basic elements of tourist infrastructure are tourist trails. They are an important element of infrastructure not only from the point of view of the tourists movement to a visited

${ }^{5}$ A. Kowalczyk, M. Derek, op.cit.

${ }^{6}$ A. Kowalczyk, M. Derek, Wybrane problemy planowania zagospodarowania turystycznego, in: Zagospodarowanie turystyczne, eds. A. Kowalczyk, M. Derek (eds), Wydawnictwo Naukowe PWN, Warszawa 2010, pp. $148-196$.

${ }^{7}$ B. Pawichrowska, A. Demianowicz, Uwarunkowanie techniczne, in: Zarządzanie turystyka na obszarach przyrodniczo cennych, ed. B. Poskrobko, Wydawnictwo Wyższej Szkoły Ekonomicznej w Białymstoku, Białystok 2005, pp. 152-168.

${ }^{8}$ S. Wiliams, Tourism Geography, Routledge Contemporary Human Geography Series, Taylor \& Francis Group, London and New York 1998, pp. 111-114.

${ }^{9}$ H. Kiryluk, Problemy rozwoju funkcji turystycznej na obszarach parków krajobrazowych, in: Bariery w zarzadzaniu parkami krajobrazowymi w Polsce, ed. K. Zimniewicz, Polskie Wydawnictwo Ekonomiczne, Warszawa 2008, pp. 101-118. 
area but also due to the proper management of tourist traffic. ${ }^{10}$ According to R. Pawlusiński the tourist trail is a route which connects attractive places and objects. Tourist trails create a coherent system across the country but also can connect with neighboring countries. They become a part of an international network then. ${ }^{11}$ It is important during planning a new tourist trail to analyze its ability to reach all the waypoints, connections with the existing system of trails, determine its attractiveness and anticipated attendance as well as its future development. ${ }^{12}$

The attractiveness of the trail depends, mostly, on natural and landscape values, but also on the infrastructure of a tourist trail. The important elements which give information about the trail are signposts and information boards. They should be located in rest places and their form and appearance should be consistent with the landscape. An important part are also the elements of small architecture such as observation towers, shelters, benches, tables, picnic areas as well as waste bins and sanitary items. ${ }^{13}$ But their type and quantity depends on the trail type. The first tourist trails in Poland were designated in 1880 by the Society of Tatra Mountains. ${ }^{14}$ The institutions responsible for the designation of new tourist trails in Poland are now the Polish Tourist and Sightseeing Society (PTTK) and authorities at local or district level. Because tourists have different needs, there is a necessity for designating specific tourist trails. In the literature on the subject there is a lot of different classification criteria of the trails. For example, Stasiak proposes the following criteria: the purpose of travel, type of transport, the subject of the trail and its range. ${ }^{15}$ The subject can be varied. There are nature trails which relate to landscape, ornithological or natural values, but also cultural trails associated with architectural monuments, historical or biographical places etc. ${ }^{16}$ With regard to the type of transport, trails are divided into: cycling, horse-riding, skiing, kayaking and sailing. An important addition to the system of tourist trails are educational and walking trails. They are usually short thematic sections of diversified nature. Their basic elements are educational boards related to the subject of a trail.

Tourist trails have different functions. The most important are the tourist and protective roles. ${ }^{17}$ It is also worth noting that they can play a role in ensuring the safety of tourists or in the economic stimulation of the areas where they are located. Their ecological function is the most important from the viewpoint of protected areas. First of all, it must be associated with the management of tourist traffic. Therefore it can be an essential tool for the proper use of protected areas. Owing to a good system of trails one can affect the dispersion of tourists and limit the penetration of the

${ }^{10}$ R. Pawlusiński, Ustugi i zagospodarowania turystyczne, in: Turystyka, ed. W. Kurek, Wydawnictwo Naukowe PWN, Warszawa 2008, pp. 164-177.

11 R. Pawlusiński, Ustugi...

12 Instrukcja znakowania szlaków turystycznych, Wydawnictwo PTTK Kraj, Warszawa 2007.

${ }^{13}$ E. Panfiluk, Zagospodarowanie turystyczne Puszczy Białowieskiej na przykładzie szlaków turystyki kwalifikowanej, in: Turystyka i rekreacja na obszarach przyrodniczo cennych $w$ regionach transgranicznych pótnocnowschodniej polski, ed. W. Chiżniak, Oficyna Wydawnicza Politechniki Białostockiej, Białystok 2009, pp. 114-125.

${ }^{14}$ Instrukcja znakowania szlaków turystycznych...

15 A. Kowalczyk, M. Derek, op.cit.

${ }^{16}$ Ibidem.

17 Ibidem. 
most valuable places. Trails are located both in the most popular and less visited areas. Particularly important is planning the system of trails properly and taking care of the necessary elements of the tourist infrastructure taking into account some factors such as their function, length, topography, established form of nature or landscape protection, existing tourist and para-tourist infrastructure. ${ }^{18}$

Tourist trails are planned by the proper commission within the Polish Tourist and Sightseeing Society (PTTK). There are Mountain, Foot, Skiing, Cycling, Equestrian and Kayak Tourism Commission in PTTK. ${ }^{19}$ They are responsible for:

- approval of new trails and decisions of changes in the system of existing trails,

- documenting and monitoring of trails,

- taking care both the system of trails and associated infrastructure. ${ }^{20}$

The basis of the planning and marking of tourist trails within the protected areas is the Nature Conservation Act of 16th of April, 2004.

\section{Landscape parks in Poland}

The nature protection system in Poland is regulated by the Nature Conservation Act of 16th of April 2004. One of the forms of nature conservation is the landscape park. Till the end of March 2015 there were 121 landscape parks in Poland, twelve of them located within the Lower Silesian Province. This form of nature conservation is established within the areas with unique natural, historical, cultural or landscape resources in order to preserve and popularize these values in terms of sustainable development. The definition shows the importance of sustainable development principles. In contrast to e.g. a national park or nature reserve, within the area of the landscape park agricultural and forest land and other properties are still in the economic use. That is why landscape parks are specific and multifunctional areas. But there must be a balance between all the elements of the environment in which man exists, so that the use of natural potential should provide realization of the needs of present and future generations. Landscape parks fulfill ecological, social, touristic, recreational, economical and even political functions. ${ }^{21}$ These functions interact differently and very often become concurrent against each other. One example would be the touristic and ecological function. It is developed in the areas of landscape parks, and to different degrees.

The Nature Conservation Act also imposes the obligation to create a protection plan within five years from the date of the landscape park establishment. This document should identify the threats and show the ways of eliminating them, provide guidance for the local authorities in the field of landscape management. Its range in relation to other spatial management documents is confirmed by the need to take it into account in the document of conditions and directions of spatial

\footnotetext{
18 Ibidem.

${ }^{19}$ Instrukcja znakowania szlaków turystycznych..

${ }^{20}$ Ibidem.

${ }^{21}$ H. Kiryluk, op.cit.
} 
development of municipalities and local spatial development plans as well as forest management plans. $^{22}$

\section{Characteristics of the Lower Silesian landscape parks}

The unique natural and landscape values of the Lower Silesian Province are protected by all possible forms of nature conservation. Due to the percentage of all legally protected areas in the Polish provinces, the Lower Silesian Province assumes 12th place $(31.9 \%)^{23}$ among 16 provinces.

Table 1. Forms of nature protection in the Lower Silesian Province

\begin{tabular}{lcc}
\hline \multicolumn{1}{c}{ Form of nature protection } & Number & Percentage of Lower Silesian Province \\
\hline National park & 2 & 0.60 \\
Natural reserve & 66 & 0.52 \\
Landscape Park & 12 & 10.40 \\
Area of protected landscape & 18 & 9.00 \\
Natura 2000 - SACs & 88 & 18.68 \\
Natura 2000 - SPAs & 11 & 15.53 \\
Ecological land & 188 & 0.20 \\
Nature and landscape complex & 16 & 0.06 \\
Geological documentation place & 1 & 0.00 \\
\hline
\end{tabular}

Source: Regional Directorate for Environmental Protection in Wrocław.

Due to the regime of nature protection, national parks and nature reserves have the highest rank in the Lower Silesian Province. However, if we take into account the percentage of forms of nature protection in the area of the Lower Silesian Province (Table 1) we can see the landscape parks, except for Natura 2,000 areas, are the most relevant. It should be noted that this is an area of landscape parks without its buffer zone. After taking into account the buffer zones $(99,229$ ha) the whole protected area of the province is greatly increased.

The landscape parks in the Lower Silesian Province have been established for over 17 years now (Table 2). The first two - the Książ and the Śnieżnica Landscape Parks were created in 1981 and the last two - in 1998 (the Jezierzyca Valley and the Sudety Wałbrzych Landscape Park). They are different in terms of the protection area, buffer zone as well as values for protection for which they were established. The Lower Silesian landscape parks protect lowland river valleys, alluvial or oak-hornbeam areas, foothill or mountain areas. They include different types of landscape for example forest, agricultural, lowland, mountain or cultural landscape. Because of the diversity of existing nature and landscape resources in landscape parks there is a possibility to develop almost

22 P. Krajewski, Ślężański Park Krajobrazowy, Dolnośląski Zespół Parków Krajobrazowych, Wrocław 2012, pp. 6-7.

${ }^{23}$ J. Burdziej, M. Kunz, Obszary chronione w Polsce - spojrzenie geoprzestrzenne, in: Systemy informacji geograficznej $w$ zarządzaniu obszarami chronionymi - od teorii do praktyki, eds. M. Kunz, A. Nienartowicz, FUH DANIEL, Tuchola-Toruń 2013, pp. 16-25. 
all available forms of tourism: family recreation, sightseeing and as well as specialized forms as skiing, kayaking and rock climbing (Raszka, Krajewski et al., 2015).

Table 2. Landscape parks in the Lower Silesian Province

\begin{tabular}{|c|c|c|c|}
\hline $\begin{array}{l}\text { Name of landscape } \\
\text { park }\end{array}$ & $\begin{array}{c}\text { Year of establishment } \\
\text { (area of landscape park) } \\
\text { (area of buffer zone) }\end{array}$ & Administrative location & $\begin{array}{l}\text { Year of protection } \\
\text { plan establishment }\end{array}$ \\
\hline $\begin{array}{l}\text { Książ Landscape } \\
\text { Park }\end{array}$ & $\begin{array}{c}1981 \\
(3,155.4 \text { ha }) \\
(5,933 \text { ha })\end{array}$ & $\begin{array}{l}\text { Wałbrzych, Stare Bogaczowice, Dobromierz, Świebodzice, } \\
\text { Swidnica }\end{array}$ & - \\
\hline $\begin{array}{l}\text { Śnieżnica Landscpe } \\
\text { Park }\end{array}$ & $\begin{array}{c}1981 \\
(28,800 \text { ha) } \\
\text { (no buffer zone) }\end{array}$ & $\begin{array}{c}\text { Złoty Stok, Kłodzko, Bystrzyca Kłodzka, Lądek Zdrój, } \\
\text { Międzylesie, Stronie Śląskie. }\end{array}$ & - \\
\hline $\begin{array}{l}\text { Ślęża Landscape } \\
\text { Park }\end{array}$ & $\begin{array}{c}1988 \\
(8,190 \text { ha }) \\
(7,450 \text { ha })\end{array}$ & $\begin{array}{c}\text { Jordanów Śl., Sobótka, Dzierżoniów, Łagiewniki, } \\
\text { Marcinowice, Świdnica. }\end{array}$ & 2012 \\
\hline $\begin{array}{l}\text { Bóbr Valley } \\
\text { Landscape Park }\end{array}$ & $\begin{array}{c}1989 \\
(12,295 \text { ha }) \\
\text { (11,475 ha) }\end{array}$ & $\begin{array}{l}\text { Jelenia Góra, Jeżów Sudecki, Stara Kamienica, Lubomierz, } \\
\text { Lwówek Śląski, Wleń, Świerzawa }\end{array}$ & 2001 \\
\hline $\begin{array}{l}\text { Rudawy Landscape } \\
\text { Park }\end{array}$ & $\begin{array}{c}1989 \\
(15,705 \text { ha }) \\
(6,600 \text { ha })\end{array}$ & $\begin{array}{c}\text { Bolków, Janowice Wielkie, m. Jelenia Góra, m. Kowary, } \\
\text { Mysłakowice, Kamienna Góra, Marciszów }\end{array}$ & 2012 \\
\hline $\begin{array}{l}\text { Sowie Mountains } \\
\text { Landscape Park }\end{array}$ & $\begin{array}{c}1991 \\
(8,140 \text { ha) } \\
\text { (no buffer zone) }\end{array}$ & $\begin{array}{c}\text { Dzierżoniów, Pieszyce, Bielawa, Głuszyca, Walim, } \\
\text { Stoszowice, Nowa Ruda }\end{array}$ & 2012 \\
\hline $\begin{array}{l}\text { Chełmy Landscape } \\
\text { Park }\end{array}$ & $\begin{array}{c}1992 \\
(15,990 \text { ha }) \\
(12,470 \text { ha })\end{array}$ & Paszowice, Męcinka, Złotoryja, Krotoszyce, Jawor & 2012 \\
\hline $\begin{array}{l}\text { Jezierzyca Valley } \\
\text { Landscape Park }\end{array}$ & $\begin{array}{c}1994 \\
(7,953 \text { ha) } \\
\text { (no buffer zone) }\end{array}$ & Wołów, Wińsko & 2012 \\
\hline $\begin{array}{l}\text { Barycz Valley } \\
\text { Landscape Park }\end{array}$ & $\begin{array}{c}1996 \\
(70,040 \text { ha) } \\
\text { (no buffer zone) } \\
\end{array}$ & $\begin{array}{l}\text { Cieszków, Krośnice, Milicz, Prusice, Trzebnica, Twardogóra, } \\
\text { Żmigród, Odolanów, Przygodzice, Sośnie }\end{array}$ & - \\
\hline $\begin{array}{l}\text { Przemków } \\
\text { Landscape Park }\end{array}$ & $\begin{array}{c}1997 \\
(22,340 \text { ha }) \\
(15,467 \text { ha }) \\
\end{array}$ & Przemków, Gaworzyce, Radwanice, Chocianów, Gromadka & project \\
\hline $\begin{array}{l}\text { Bystrzyca Valley } \\
\text { Landscape Park }\end{array}$ & $\begin{array}{c}1998 \\
(8,570 \text { ha) } \\
\text { (no buffer zone) }\end{array}$ & Wrocław, Kąty Wrocławskie, Mietków, Sobótka, Miękinia & - \\
\hline $\begin{array}{l}\text { Sudety Wałbrzyskie } \\
\text { Landscape Park }\end{array}$ & $\begin{array}{c}1998 \\
(6,493 \mathrm{ha}) \\
(2,894 \mathrm{ha})\end{array}$ & $\begin{array}{c}\text { Czarny Bór, Mieroszów, Głuszyca, Wałbrzych, Boguszów } \\
\text { Gorce, Jedlina Zdrój }\end{array}$ & project \\
\hline
\end{tabular}

Source: B. Mastalska-Cetera, P. Krajewski, Plany ochrony parku krajobrazowego jako narzędzie zrównoważonego rozwoju, „Problemy Ekologii Krajobrazu” 2014, t. 37, pp. 147-154.

The development of parks is different in terms of both quantity and quality. The dominant form of tourism in the Lower Silesian landscape parks is hiking with the exception of the Przemkowski Landscape Park where cycling is the most important. The main objective of the tourism development within protected areas is the management of tourist traffic in such a way 
that its impact on the environment is minimized. There is about $490 \mathrm{~km}$ of tourist trails within the borders of the analyzed landscape parks. They also include thematic ones:

- archeological trails (Jezierzyca Valley Landscape Park, Ślęża Valley Landscape Park),

- geological trails, for example, Trail of Extinct Volcanoes (Chełmy Landscape Park),

- cultural trails, for example, Trail of Piast Castles (Rudawy Landscape Park, Bóbr Valley Landscape Park),

- hiking trails, for example, The Main Sudety Trail by Mieczysław Orłowicz (Rudawski Landscape Park, Sowie Mountains Landscape Park and others).

A lot of cycling trails and 36 educational trails are added to the system, of tourist trails in the study area. Particularly interesting are the educational trails in the Myślibórz Gorge and down the slope of the Basaltic Mountain in the Chełmy Landscape Park as well as the trail around the Przemków Ponds in the Przemków Landscape Park.

The highest density of tourist trails is within the Sowie Mountains and the Ślężański Landscape Park - about $90 \mathrm{~km}$ for each $100 \mathrm{~km}^{2}$ and the lowest density is within the Przemkowski Landscape Park - about $27 \mathrm{~km}$ for each $100 \mathrm{~km}^{2}$ (Table 3). The main cause of it is the large area covered by forest.

Table 3. Tourist infrastructure in landscape parks with protection plans

\begin{tabular}{|c|c|c|c|c|c|c|}
\hline $\begin{array}{c}\text { Name of landscape } \\
\text { park }\end{array}$ & $\begin{array}{c}\text { Number } \\
\text { of tourist trails } \\
\text { [pcs.] }\end{array}$ & $\begin{array}{c}\text { Lenght of tourist } \\
\text { trails } \\
{[\mathrm{km}]}\end{array}$ & $\begin{array}{c}\text { Density } \\
\text { of tourist trails } \\
{\left[\mathrm{km} / 100 \mathrm{~km}^{2}\right]}\end{array}$ & $\begin{array}{c}\text { Number } \\
\text { of educational } \\
\text { trails [pcs.] }\end{array}$ & $\begin{array}{c}\text { Number } \\
\text { of cycling trails } \\
\text { [pcs.] }\end{array}$ & $\begin{array}{c}\text { Number of view } \\
\text { points } \\
\text { [pcs.] }\end{array}$ \\
\hline $\begin{array}{l}\text { Ślężański Landscape } \\
\text { Park }\end{array}$ & 5 & 72 & 87.91 & 4 & 5 & 4 \\
\hline $\begin{array}{l}\text { Bóbr Valley } \\
\text { Landscape Park }\end{array}$ & 7 & 61 & 49.61 & 5 & 5 & 8 \\
\hline $\begin{array}{l}\text { Rudawski Landscape } \\
\text { Park }\end{array}$ & 12 & 69 & 43.93 & 4 & 9 & 9 \\
\hline $\begin{array}{l}\text { Sowie Mountains } \\
\text { Landscape Park }\end{array}$ & 8 & 75 & 92.13 & 4 & 6 & 1 \\
\hline $\begin{array}{l}\text { Chełmy Landscape } \\
\text { Park }\end{array}$ & 4 & 112 & 70.04 & 10 & 2 & 4 \\
\hline $\begin{array}{l}\text { Jezierzyca Valley } \\
\text { Landscape Park }\end{array}$ & 5 & 41 & 51.55 & - & 3 & - \\
\hline $\begin{array}{l}\text { Przemków Landscape } \\
\text { Park }\end{array}$ & 3 & 60.5 & 27.08 & 6 & 6 & 1 \\
\hline $\begin{array}{l}\text { Sudety Wałbrzyskie } \\
\text { Landscape Park }\end{array}$ & 11 & no data & no data & 3 & 13 & 2 \\
\hline
\end{tabular}

Source: made by the authors. 


\section{Tourist trails in protection plans of the Lower Silesian landscape parks}

An analysis of tourism development plans (an obligatory part of protection plans of the Lower Silesian landscape parks) allows for yet another typology of landscape parks. In terms of tourists' interest parks can be identified as of:

- low tourist importance (Jezierzyca Valley Landscape Park, Bystrzyca Valley Landscape Park, Przemków Landscape Park),

- medium tourist importance (Sudety Wałbrzyskie Landscape Park, Chełmy Landscape Park),

- high tourist importance (Ślęża Landscape Park, Rudawa Landscape Park, Sowie Mountains Landscape Park).

The most frequently listed reasons for the low tourist interest are the distance from urban centers, lowland character of protected area, and low accommodation possibilities.

The protection plans of most landscape parks emphasize that the system of tourist trails does not have to be changed. Among the parks with the low density of tourist trails only the protection plan of the Bóbr Valley Landscape Park indicates a possible opportunity to enrich the tourist offer by new cycling trails, educational trails and one more walking trail. The information about the need to expand the existing system of trails appear occasionally (eg. the Chełmy Landscape Park) in the rest of protection plans (Table 4).

Table 4. System of tourist trails in protection plans of Lower Silesian landscape parks

\begin{tabular}{|c|c|}
\hline Name of landscape park & Activities in protection plan connected with system of tourist trails \\
\hline 1 & 2 \\
\hline Ślęża Landscape Park & $\begin{array}{l}\text { The existing system of tourist trails requires some changes. } \\
\text { - it is necessary to repair paths with tourist trails. Because of total destruction of some paths, the blue } \\
\text { tourist trail should be planned one more time, } \\
\text { - marking of tourist, educational and thematic trails should be repaired, } \\
\text { - proposal to plan new cycling trail connected with international cycling trail Euro Velo (R9) }\end{array}$ \\
\hline Bóbr Valley Landscape & System of tourist trails responds to the needs of tourist, however: \\
\hline Park & $\begin{array}{l}\text { - new tourist trail along the Bóbr valley should be planned, } \\
\text { - two of existing tourist trails should be modified, } \\
\text { - two more cycling trails should be planned, } \\
\text { - three educational trails should be planned }\end{array}$ \\
\hline Rudawy Landscape Park & $\begin{array}{l}\text { System of tourist trails needs some changes: } \\
\text { - marking of tourist, educational and thematic trails is not sufficient and should be repaired, } \\
\text { - there is the need for new educational, horse and skiing trails, } \\
\text { - it is not enough tourist infrastructure connected with tourist trails, } \\
\text { - there is the need to concentrate and control tourist traffic }\end{array}$ \\
\hline Sowie Mountains & System of tourist trails is correct and does not have to be changed: \\
\hline Landscape Park & $\begin{array}{l}\text { - new educational trails should be planned, } \\
\text { - some parts of the trails should be repaired }\end{array}$ \\
\hline Chełmy Landscape Park & $\begin{array}{l}\text { System of tourist trails needs some changes: } \\
\text { - proposal to plan two new tourist trails, } \\
\text { - it is necessary to mark educational and walking trails once again, } \\
\text { - it is necessary to designate one institution responsible for maintaining existing tourist trails, } \\
\text { - it is necessary to maintain tourist trails in good condition, } \\
\text { - proposal to rebuild existing viewing tower and build new one at the top of the Dębnica mountain }\end{array}$ \\
\hline
\end{tabular}




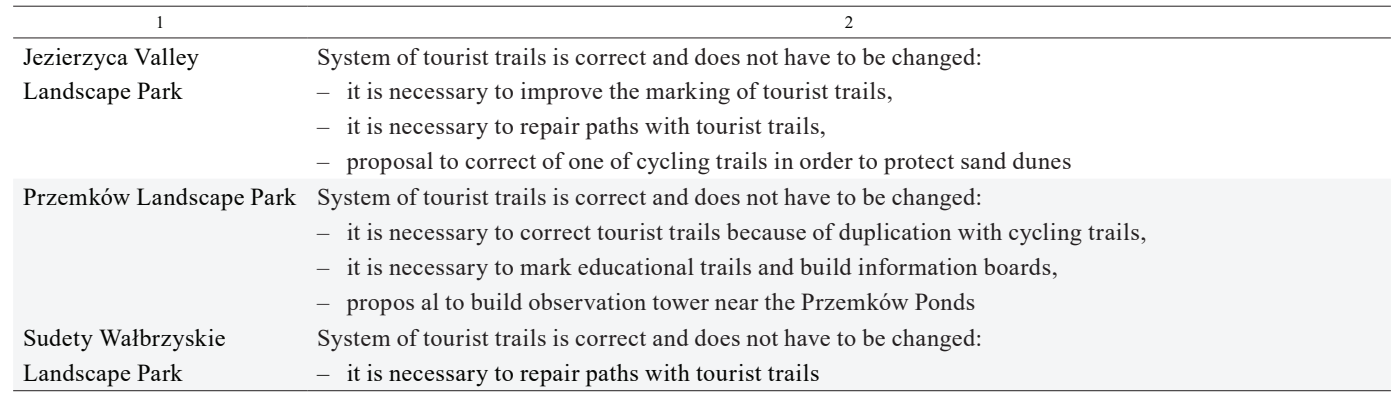

Source: made by the authors on the basis of the protection plans of selected landscape parks - tourism development parts (see References).

The environmental risks identified in protection plans are not associated with too intensive use of tourist trails. Rather, it is a result of the bad condition of some tourist trails or occasionally intense tourist traffic in individual parks during the weekend e.g. the Ślęża Landscape Park. However, it is necessary to point out that in most cases the potential risks are associated with the new forms of tourism (motocross and quads) or the development of recreational functions and the fear of expanding the area with recreational buildings.

The appropriate condition of the tourist infrastructure of protected areas can help to reduce the negative influence of tourists on the environment. Therefore, it is worth noting that an important part of protection plans are indications of the need for constant monitoring the existing tourism infrastructure condition. In all documents there is the information on the need to improve, standardize and repair marking of the trails and repair the paths with trails. They are often neglected and overgrown. That is the reason why tourists do not want to walk there. Particularly emphasized is also the bad condition of the trails in the Jezierzyca Valley Landscape Park.

The majority of the parks are located within the areas belonging to different municipalities. This negatively influences the standardization of the tourism development. One good example can be the Sudety Wałbrzyskie Landscape Park where the system of the cycling trails has been created by local initiatives in the form of loops in each municipality. This is advantageous from the point of view of residents, but disadvantageous for tourists and also for the environment. The lack of coordination of activities related to the tourist infrastructure is also observable in the Chełmy Landscape Park. Spychała claims that in the case of the Barycz Valley Landscape Park the protection plan could provide the development of the tourist infrastructure taking into account the specificity of this area. In the current situation, the development of tourism in the park is unequal and dominates only within two of the ten communes. ${ }^{24}$

${ }^{24}$ A. Spychała, Zagospodarowanie turystyczne Parku Krajobrazowego „Dolina Baryczy”, “Problemy Ekologii Krajobrazu" T. XXV, pp. 85-93. 


\section{Conclusions}

The problems and indications identified in the article confirm the necessity of preparing protection plans for landscape parks. They provide a series of guidelines for direct protection of fauna and flora as well as the spatial and tourism management within the landscape parks. Tourist development documentations identify potential and real threats and define solutions to eliminate them. Therefore these analyses are a good basis for the planning of tourism development, taking into account the needs of nature conservation. Unfortunately this type of documents have not been prepared yet for all the parks. The documents for one of the parks are outdated (the Bóbr Valley Landscape Park) and should be revised.

\section{References}

Burdziej J., Kunz M., Obszary chronione w Polsce - spojrzenie geoprzestrzenne, in: Systemy informacji geograficznej $w$ zarzadzaniu obszarami chronionymi - od teorii do praktyki, eds. M. Kunz A. Nienartowicz, FUH DANIEL, Tuchola-Toruń 2013.

Instrukcja znakowania szlaków turystycznych, Wydawnictwo PTTK Kraj, Warszawa 2007.

Kiryluk H., Problemy rozwoju funkcji turystycznej na obszarach parków krajobrazowych, in: Bariery w zarządzaniu parkami krajobrazowymi w Polsce, ed. K. Zimniewicz, Polskie Wydawnictwo Ekonomiczne, Warszawa 2008.

Kowalczyk A., Derek M., Przedmiot zagospodarowania turystycznego, in: Zagospodarowanie turystyczne, eds. A. Kowalczyk, M. Derek, Wydawnictwo Naukowe PWN, Warszawa 2010.

Kowalczyk A., Derek M., Wybrane problemy planowania zagospodarowania turystycznego, in: Zagospodarowanie turystyczne, eds. A. Kowalczyk, M. Derek, Wydawnictwo Naukowe PWN, Warszawa 2010.

Kozłowska U., Korzeń J., Plan ochrony Parku Krajobrazowego Doliny Bobru. Operat ochrony walorów rekreacyjnych, turystycznych i wypoczynkowych, Jelenia Góra 1999.

Krajewski P., Ślężański Park Krajobrazowy, Dolnośląski Zespół Parków Krajobrazowych, Wrocław 2012.

Kurek W., Mika M., Turystyka jako przedmiot badań naukowych, in: Turystyka, ed. W. Kurek, Wydawnictwo Naukowe PWN, Warszawa 2008.

Mastalska-Cetera B., Krajewski P., Plany ochrony parku krajobrazowego jako narzędzie zrównoważonego rozwoju, „Problemy Ekologii Krajobrazu” 2014, Vol. 37, 2014.

Panfiluk E., Zagospodarowanie turystyczne Puszczy Białowieskiej na przykładzie szlaków turystyki kwalifikowanej, in: Turystyka i rekreacja na obszarach przyrodniczo cennych w regionach transgranicznych pótnocno-wschodniej polski, ed. W. Chiżniak, Oficyna Wydawnicza Politechniki Białostockiej, Białystok 2009.

Pawichrowska B., Demianowicz A., Uwarunkowanie techniczne, in: Zarzadzanie turystyka na obszarach przyrodniczo cennych, ed. B. Poskrobko, Wydawnictwo Wyższej Szkoły Ekonomicznej w Białymstoku, Białystok 2005.

Pawlusiński R., Ustugi i zagospodarowania turystyczne, in: Turystyka, ed. W. Kurek, Wydawnictwo Naukowe PWN, Warszawa 2008.

Potocki J., Plan ochrony Parku Krajobrazowego „Chetmy”. Operat zagospodarowania turystycznego, WarszawaWrocław 2009.

Potocki J., Plan ochrony Parku Krajobrazowego Gór Sowich. Operat zagospodarowania turystycznego, WarszawaWrocław 2010.

Potocki J., Plan ochrony Ślężańskiego Parku Krajobrazowego. Operat zagospodarowania turystycznego, WarszawaWrocław 2010.

Potocki J., Plan ochrony Parku Krajobrazowego „Dolina Jezierzycy”. Operat zagospodarowania turystycznego, Warszawa-Wrocław 2011.

Potocki J., Projekt Planu ochrony Przemkowskiego Parku Krajobrazowego. Operat zagospodarowania turystycznego, Brzeg 2013. 
Potocki J., Krawczyszyn N., Projekt Planu ochrony Parku Krajobrazowego Sudetów Watbrzyskich. Operat zagospodarowania turystycznego, Brzeg 2013.

Raszka B., Krajewski P., Kalbarczyk E., Kalbarczyk R., Kasprzak K., Parki krajobrazowe w Polsce, Wydawnictwo Dragon, Bielsko-Biała 2015.

Rochowski P., Plan ochrony Rudawskiego Parku Krajobrazowego. Operat ochrony walorów krajobrazowych i kulturowych, Kraków 2008.

Spychała A., Zagospodarowanie turystyczne Parku Krajobrazowego „Dolina Baryczy”, "Problemy Ekologii Krajobrazu” T. XXV.

Wiliams S., Tourism Geography, Routledge Contemporary Human Geography Series, Taylor \& Francis Group, LondonNew York 1998.

Ziółkowski R., Funkcje turystyczno-rekreacyjne obszarowej ochrony przyrody w świetle uwarunkowań prawnych, in: Turystyka i rekreacja na obszarach przyrodniczo cennych $w$ regionach transgranicznych północno-wschodniej polski, ed. W. Chiżniak, Oficyna Wydawnicza Politechniki Białostockiej, Białystok 2009.

\section{KSZTAŁTOWANIE SZLAKÓW TURYSTYCZNYCH W PLANACH OCHRONY DOLNOŚLĄSKICH PARKÓW KRAJOBRAZOWYCH}

SŁOWA KLUCZOWE STRESZCZENIE park krajobrazowy, szlak turystyczny, plan ochrony, Dolny Śląsk, ochrona przyrody

Parki krajobrazowe powoływane są ze względu na wyjątkowe walory przyrodniczo-krajobrazowe. Mogą one pełnić różne funkcje. Często cele ochronne parków kolidują z ich funkcjami turystyczno-rekreacyjnymi. Warunkiem prawidłowego udostępnienia walorów parków dla potrzeb turystów powinno być dostosowane do jego uwarunkowań zagospodarowanie turystyczne. Jednym z elementów zagospodarowania turystycznego są szlaki turystyczne. Ich sieć oraz stan techniczny wpływają na organizowanie ruchu turystycznego. Celem opracowania jest analiza zapisów planów ochrony parków krajobrazowych ze względu na zawarte w nich wytyczne do kształtowania zagospodarowania turystycznego. Analizom poddano operaty oraz projekty operatów zagospodarowania turystycznego dla 8 spośród 12 dolnośląskich parków krajobrazowych. Operaty zagospodarowania turystycznego identyfikują w granicach parków zagrożenia potencjalne oraz rzeczywiste, określają rozwiązania sprzyjające eliminowaniu tych zagrożeń. Tym samym dają podstawy do właściwego planowania rozwoju turystycznego uwzględniającego ochronę walorów. Przeprowadzone analizy wskazują, iż w większości parków sieć szlaków jest wystarczająca, pojawiają się pojedyncze propozycje drobnych uzupełnień. Identyfikowane zagrożenia dla środowiska naturalnego nie wiążą się z nazbyt intensywnym użytkowaniem szlaków. Wskazano jednak na konieczność utrzymania szlaków turystycznych w należytym stanie, eliminację niedociągnięć oraz w przypadku pojedynczych parków potrzebę bardziej równomiernego w czasie rozłożenia ruchu turystycznego. 